\title{
PERAN PROMOSI DAN LOKASI DALAM MENINGKATKAN PENJUALAN UNIT PERUMAHAN PURI DELTA ANGSANA DI KECAMATAN KASEMEN KOTA SERANG
}

\author{
Abdul Aziz ${ }^{1}$, Sahrul Arixona ${ }^{2}$ \\ ${ }^{12}$ Universitas Bina Bangsa \\ *azizkakang82@gmail.com
}

\begin{abstract}
ABSTRAK
Tujuan penelitian ini adalah untuk mengetahui apakah ada pengaruh secara pasial dan simultan dalam promosi dan lokasi dalam meningkatkan penjualan unit perumahan puri delta angsana di kecamatan kasemen. Metode penelitian yang digunakan adalah metode penelitian kuantitatif. Populasi penelitian adalah Perumahan Puri Delta Angsana di Kecamatan KasemenKota Serangyang tercatat pada tahun 2021 sebanyak 72 Unit perumahan teknik analisis data yang digunakan peneliti meliputi statistik deskriptif, uji validitas, uji reliabilitas, uji asumsi klasik, uji regresi linier berganda, uji koefisien korelasi, uji determinasi, uji $T$, dan uji F. Hasilpenelitian ini menunjukan bahwa promosi secara parsial berpengaruh signifikan terhadap penjualan nilai thitung sebesar 2,894 > nilai $t_{\text {tabel }}$ sebesar 1,666, nilai signifikan sebesar 0,004 <0,05. Lokasi secara parsial berpengaruh signifikan terhadap penjualan nilai $t_{\text {hitung }}$ sebesar 3,248> tabel sebesar 1,666 nilai signifikan sebesar 0,005 <0,05. Promosi $\left(X_{1}\right)$, dan Lokasi $\left(X_{2}\right)$ secarabersama-sama (simultan) berpengaruh signifikan terhadap Penjualan $(Y)$ pada Perumahan PuriDelta Angsana di Kecamatan Kasemen Kota Serang dengan nilai signifikan 0,000 $<0,05$ dannilai $F_{\text {hitung }} 16,664>3,13$. Nilai koefisien determinasi ( $R$ Square) yang diperoleh sebesar 0,326. Hal ini berarti $32,6 \%$ variasi penjualan dapat dijelaskan oleh variabel Promosi dan Lokasi. Sedangkan sisanya 67,4\% dipengaruhi oleh variabel lain yang tidak dimasukkan dalam penelitian.
\end{abstract}

Kata kunci: Promosi, Lokasi, Penjualan

\begin{abstract}
The purpose of this study was to determine whether there is a partial and simultaneous influence on promotion and location in increasing sales of Puri Delta Angsana housing units in Kasemen District. The research method used is quantitative research methods. The research population is Puri Delta Angsana Housing in Kasemen District, Serang City which was recorded in 2021 as many as 72 housing units. The data analysis techniques used by researchers include descriptive statistics, validity tests, reliability tests, classical assumption tests, multiple linear regression tests, correlation coefficient tests, test determination, $T$ test, and $F$ test. The results of this study indicate that promotion partially has a significant effect on sales, the tcount value is $2.894>$ ttable value is 1.666 , the significant value is $0.004<0.05$. Location partially has a significant effect on sales, tcount value is 3,248> ttable is 1,666, significant value is 0.005 $<0.05$. Promotion (X1), and Location (X2) together (simultaneously) have a significant effect on Sales (Y) at Puri Delta Angsana Housing in Kasemen District, Serang City with a significant value of $0.000 b<0.05$ and an $F$ value of $16.664>3,13$. The coefficient of determination $(R$ Square) obtained is 0.326 . This means that $32.6 \%$ of the sales variation can be explained by the Promotion and Location variables. While the remaining $67.4 \%$ is influenced by other variables not included in the study.
\end{abstract}

Keywords: Promotion, Location, Sales

\section{PENDAHULUAN}

Pertumbuhan penduduk yang cukup tinggi khususnya di ibu kota Provinsi akan berakibat pada kebutuhan sandang, pangandan papan yang menjadi kebutuhan pokok manusia terus meningkat. Ada dua faktor yang mempengaruhi migrasi yaitu factor dorong dan faktor tarik. Faktor dorong terjadi karena di kota kecil memiliki lebih sedikit pekerjaan yang tersedia, 
Prosiding The 1st National Conference on Applied Business, Education, \& Technology (NCABET)"

Unversitas Bina Bangsa 2021

DOI Article : 10.46306/ncabet.v1i1.48

gaji upah rendah, kebiasaan penyewa buruk, dan kondisi hidup yang buruk. Faktor tarikan adalah kebalikan dari faktor dorongan, faktor mana yang termasuk kondisi yang tersedia di ibu kota.

Perumahan Puri Delta Angsana di Kecamatan Kasemen Kota Serang adalah perumahan subsidi yang berlokasi kan di Jl.Akses Pabrik/ Gedung, Kasemen, Kec. Kasemen, Kota Serang, Banten. Berdirinyaperusahaan ini sejak tahun 2010 atasprakarsa pengusaha dan profesional, dari awal berdirinya perumahan Puri DeltaAngsana di Kecamatan Kasemen Kota Serang memberikan pelayanan yang baik kepada konsumen, cara karyawan melayanicalon konsumen sebelum melakukan pembelian, dengan berbagai cara yaitu dengan mengantarkan konsumen langsun untuk melihat keadaan rumah dan menjawab pertanyaan-pertanyaan yang diajukan konsumen, semisal harga sebelumakad pembelian dan lain sebagainya.

Pangsa pasar perumahan ini mayoritas diperuntukan untuk masyarakat luar daerah Kota Serang, masyarakat yang berprofesi wiraswasta atau pengusaha, masyarakat yang memiliki pendapatan di atas 10 juta, tetapi tidak bisa dipungkiri banyak konsumen yang dikatakan mampu dalam membeli perumahan ini. Mengingat harga perumahan yang bisa dikatakan mahal dibanding perumahan yang lain tetapi ini dilihat dari letak atau lokasi dari perumahanyang berada di pusat kota, selain itu juga fasilitas yang tidak kalah dengan perumahan lainnya, lalu rumah yang siap huni bagi pembelinya, dan strategi bisnis yang menjanjikan. Semakin dekat sebuah rumah dengan kota maka semakin tinggi harganya dari tahun ke tahun.

Salah satu kegiatan agar tercapainya kesuksesan pemasaran adalah perusahaan dapat memaksimalkan promosinya.Kegiatan promosi ini merupakan komunikasi perusahaan dengan konsumen yaitu dapat dilakukan dengan beberapa carayang disebut dengan bauran promosi. Menurut (Sunyoto, 2012), bauran promosi adalah unsur dalam bauran pemasaranperusahaan yang didayagunakan untuk memberitahukan, membujuk, dan mengingatkan tentang produk perusahaan.

Perumahan Puri Delta Angsana diKecamatan Kasemen Kota Serang mempunyai beberapa kendala dalam menjalankan strategi promosi diantaranya, kurangnya informasi di pasar mengenai produk yang dijual oleh Perumahan Puri Delta Angsana di Kecamatan Kasemen sehingga mempengaruhi hasil dari strategi promosi yang dijalankan dan hasil yang didapat tidak sesuai dengan target yang ditetapkan.

Promosi biasanya dilakukan untuk menarik konsumen agar membeli produk tertentu. Akan tetapi banyaknya promosi yang dilakukan oleh perusahaan sepunuhnya tidak menarik konsumen untukmembeli produk tersebut. Dilihat dari data promosi yang dilakukan oleh 
Prosiding The 1st National Conference on Applied Business, Education, \& Technology (NCABET)"

Unversitas Bina Bangsa 2021

DOI Article : 10.46306/ncabet.v1i1.48

Perumahan Puri Delta Angsana di Kecamatan KasemenKota Serang dalam menjual perumahan bersubsidi kepada konsumen dapat dilihat pada Tabel 1 berikut ini:

Tabel 1 Data Promosi Perumahan PuriDelta Angsana di Kecamatan Kasemen Kota Serang

\begin{tabular}{|c|c|c|}
\hline Pramosi & Keterangall & Penzelwaran BUsya \\
\hline Meden Soxial & $\begin{array}{l}\text { Faceloods, } \\
\text { linotigram }\end{array}$ & Gratix \\
\hline Media Cesak & $\begin{array}{l}\text { Baleho } \\
\text { 5punduk }\end{array}$ & 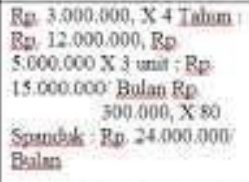 \\
\hline Dutect Seling Team & $\begin{array}{l}\text { Pusat } \\
\text { keramsian } \\
\text { Event } \\
\text { Dina }\end{array}$ & Re $5,000,000$ Teinn Bulan \\
\hline
\end{tabular}

Sumber: Perumahan Puri Delta Angsana di KecamatanKasemen Kota Serang, 2020

Pada Tabel 1 dimana hasil data promosi menunjukkan bahwa media sosial yang terdiri dari facebook, forum jual beli, instagram, biaya pengeluaran tidak ada, pada media cetak yang terdiri dari biaya pengeluaran sebesar Rp. 3.000.000, X 4 tahun total Rp. 12.000.000, baleho sebesar Rp.5.000.000/bulan X 3 unit pemasangan total Rp. 15.000.000, dan spanduk Rp.300.000, X 80 spanduk total Rp. 24.000.000. Jika dilihat promosi direct selling team yang terdiri dari pusat keramaian, event dan dinas sebesar Rp.8.000.000,/perteam/bulan terdapat 6 orang.

Produk yang dipasarkan tidak dapatditerima sepenuhnya oleh customer. Jadiinformasi pasar sangat mempengaruhi hasildari strategi yang dijalankan. Apabila perusahaan tidak menetapkan strategi promosi yang tepat maka perusahaan tidakdapat hidup dan berkembang karena itu hendaklah setiap perusahaan harus dapatmenetapkan cara dan strategi yang tepat sehingga akhirnya dapat bersaing dan merebut pasar yang ada dan semakinketatnya persaingan didalam dunia usaha pada saat sekarang ini, membuat para pelaku usaha baik itu perseorangan atau persekutuan, ataupun dalam bentuk perusahaan baik itu perusahaan kecil atau besar haruslah memiliki faktor yang dapat dijadikan oleh perusahaan sebagai senjata dalam usahanya untuk memenangkanpersaingan dengan para pesaingnya diduniabisnis. Kondisi seperti itulah yang pada akhirnya menyebabkan para pelaku usaha tersebut makin gencar berusaha untuk mencari solusi maupun program bisnis yang dapat meningkatkan daya saing perusahaan didalam bisnisnya. Semakin tinggi harapan pelanggan maka akan semakin sulit pula untuk menciptakanpromosi terbaik untuk memengaruhi penjualan.

Tempat atau lokasi rumah merupakansalah satu faktor utama yang perlu diperhatikan perusahaan untuk menarik minat konsumen dalam membeli rumah.Lokasi merupakan letak atau toko pengecerpada daerah yang strategis sehingga dapat memaksimumkan laba. ${ }^{1}$ Memilih lokasiberdagang merupakan keputusan pentinguntuk bisnis yang harus membujuk pelanggan 
Prosiding The 1st National Conference on Applied Business, Education, \& Technology (NCABET)"

Unversitas Bina Bangsa 2021

DOI Article : 10.46306/ncabet.v1i1.48

untuk datang ke tempat bisnis dalam pemenuhan kebutuhannya. Namun dalam pembahasan ini tentang bauranpemasaran berupa lokasi perumahan disini konsentrasikan pada pengertian sebagai lokasi fisik perumahan. Ini berarti tempat dimana produk dan jasa bank disediakan untuk dapat dibeli dan dimanfaatkan oleh pelanggan. Termasuk lokasi perumahan disini adalah letak perumahan. (Mursid, 2013).

Pada usaha bisnis property, strategi lokasi merupakan salah satu faktor pentingyang harus diperhatikan karena sebelum memutuskan untuk berkunjung, konsumen tentu akan mempertimbangkan juga lokasi dari tempat tersebut, karena para pembeli cenderung akan memilih membeli rumah yang memiliki lokasi strategis. ${ }^{2}$

Keunggulan dari perumahan ini memiliki lokasi yang sangat strategis, karena perumahan ini letaknya yang sangatdekat dengan pusat kota jadi akses atau jikaingin kemanapun kita pergi sangat mudah, mulai dari toko, swalayan, pusat perbelanjaan bahan-bahan kebutuhan sangat dekat dan terjangkau aksesnya. Meskipun perumahan mempunyai lokasi yang strategis akan tetapi masih terdapat kendala yaitu minimnya fasilitas padaperumahan Puri Delta Angsana di Kecamatan Kasemen Kota Serang dirasa kurang baik oleh banyak konsumen/pembeli sehingga hal ini yang menjadi hambatan bagi konsumen untuk beraktifitas dalam kehidupan sehari-hari. (Tjiptono, \& Fandy, 2015)

Dengan menggunakan strategi marketing mix diatas, penjualan rumah bersubsidi berhasil dilakukan oleh Puri Delta Angsana di Kecamatan Kasemen Kota Serang yang ada di Pangkalpinangpada tahun 2014 sampai dengan tahun 2020dapat di lihat pada grafik 1 berikut :

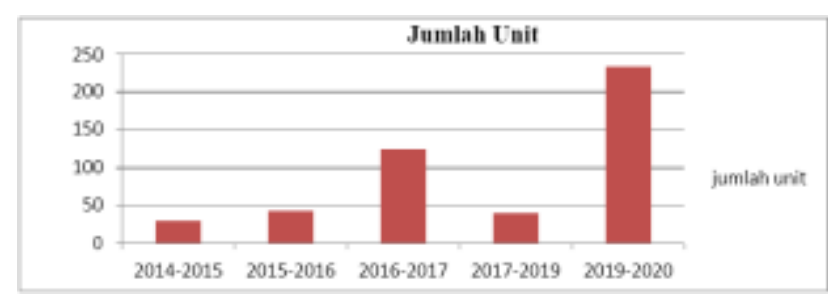

Sumber: Puri Delta Angsana di Kecamatan Kasemen KotaSerang (Bulan Agustus 2020

Gambar 1 Daftar Volume Penjualan

Dilihat dari Gambar 1 penjualanperumahan subsidi Puri Delta Angsana di Kecamatan Kasemen Kota Serang pada tahun 2014 sampai dengan tahun 2020 berjumlah 411 unit dari 458 unit yang diproduksikan dan dimana sisa penjualan unit yang belum terjual sampai dengan bulan juni 2020 adalah 47 unit rumah subsidi. Secara grafik penjualan perumahansubsidi Puri Delta Angsana di Kecamatan Kasemen Kota Serang dari pertamapembangunan perumahan 
subsidi.

Spesifikasi dari perumahan PuriDelta Angsana di Kecamatan Kasemen Kota Serang menggunakan konsep mewah dan modern, mengingat letak perumahan ini sangat strategis dengan pusat kota, terlebih lagi rumah yang siap huni, jadimereka menjual rumah dengan membangun rumah dahulu dan memperindah interior dan eksterior dari rumah tersebut kemudianmereka baru menjualnya. Jadi ini bisa dikatakan rumah yang siap huni. Untuk tipetipe rumah yang ditawarkan juga bervariasi, mulai dari rumah tipe 56 atau 56plus dengan kisaran harga 500.000 jutaan, kemudian tipe 60 dengan kisaran harga

625.000 jutaan, rumah tipe 70 dengan kisaran harga 750.000 jutaan. Tetapi hargaharga tersebut mengalami kenaikan seiring dengan berjalannya waktu dan perkembangan, karena nilai dari tanah selalu mengalami kenaikan.

Penjualan merupakan hasil akhir yang dicapai perusahaan dari hasil penjualan produk yang dihasilkan oleh perusahaan tersebut. Volume penjualantidak memisahkan secara tunai maupun kredit tetapi dihitung secara keseluruhandari total yang dicapai. Seandainya volume penjualan meningkat dan biaya distribusi menurun maka tingkat pencapaian laba perusahaan juga menurun. Peran promosi dan tempat yang efektif diharapkan dapat meningkatkan volume penjualan pada PuriDelta Angsana di Kecamatan Kasemen Kota Serang.

\section{METODE PENELITIAN}

Penelitian ini dilakukan di Jl. Akses Pabrik/ Gedung, Kasemen, Kec. Kasemen, Kota Serang, Banten 42191, Indonesia. Dan dilakukan dalam kurun waktu 4 bulan mulai dari Juni 2021 - September 2021. Penelitian inimenggunakan metode kuantitatif dengan mengambil data primer dan menggunakan metode kuisioner. Jenis penelitian ini adalah penelitian asosiatif. Penelitian asosiatif adalah penelitian yang dilakukan untuk mengetahuihubungan antara dua variabel atau lebih, yang kemudian terbentuk suatu teori yang berguna untuk meramalkan dan menjelaskan suatu fenomena.Penelitian ini dalam penyusunannya menggunakan teknis penelitian kuantitatif. Penelitian kuantitatif adalah jenis penelitian untuk menghasilkan penemuan yangdiperoleh dengan prosedur statistika atau dengan cara pengukuran. (V. Wiratna Sujarweni, 2015)

Populasi penelitian adalah Perumahan Puri Delta Angsana di Kecamatan Kasemen Kota Serang yang tercatat pada tahun 2021 sebanyak 72 Unit perumahan. Karena ukuran populasi tersebut mencukupi dan terjangkau untuk diteliti maka sampel penelitian adalahanggota populasi yaitu Perumahan Puri Delta Angsana di Kecamatan Kasemen Kota Serang. Penarikan sampel ini berpedoman pada pendapat Sugiyono yangmengatakan jika populasi kurang dari 
100 lebih baik semua diambil sebagai sampel sehingga penelitian ini merupakan penelitian populasi (sensus). Jadi jumlahsampel dalam penelitian ini sebanyak 72 unit Perumahan Puri Delta Angsana di Kecamatan Kasemen Kota Serang.

Teknik analisis data merupakan bentuk penerapan suatu metode dalam melakukan pengolahan data yang diperolehsebelumnya untuk mendapatkan sebuah kesimpulan. Penelitian ini menggunakan perangkat SPSS 24 for Windows sebagai perantara dalam melakukan analisa data.

Analisis regresi liniear berganda adalah hubungan secara linear antara variabel bebas dan terikat. Dalam analisis regresi berganda memprediksi nilai dari variabel terikat apabila variabel bebas mengalami kenaikan atau penurunan dan untuk mengetahui arah hubungan antara variabel bebas dan varibel terikat apakah masing-masing variabel berhubungan positif atau negatif. Untuk mengetahui pengaruhnya digunakan formulasi sebagai berikut :

$\mathrm{Y}=\mathrm{a}+\mathrm{b} 1 \mathrm{X} 1+\mathrm{b} 2 \mathrm{X} 2+\mathrm{e}$

Uji ketepatan perkiraan $\left(\mathrm{R}^{2}\right)$ dilakukan untuk mendeteksi ketepatan yang baik dalam analisis regresi. Uji hipotesis menggunakan uji t untuk menguji signifikansi konstanta dan setiap variabel independen akan berpengaruh terhadapvariabel dependen dan uji $\mathrm{F}$ pada taraf siginifikansi $5 \%$

\section{HASIL DAN PEMBAHASAN}

\section{Hasil Uji Validitas}

Dalam pengukuran ini sampel yang diambil untuk uji validitas sebanyak 55 responden dan diolah dengan kriteria sebagai berikut: apabila $\mathrm{r}_{\text {hitung }}$ lebih besar daripada (>) $\mathrm{r}_{\text {tabel}}$, maka dinyatakan valid. Untuk penelitian ini nilai $\mathrm{r}$ tabel yang diperoleh adalah:

$$
\begin{aligned}
& \mathrm{df}=\mathrm{n}-2 \\
& \mathrm{df}=73-2=70
\end{aligned}
$$

Berdasarkan hasil $\mathrm{df}=53$ dan dengan taraf signifikansi 5\% atau 0,05, maka

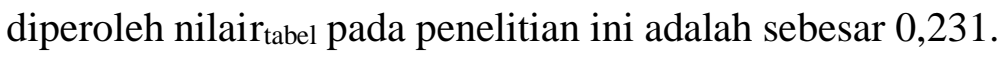




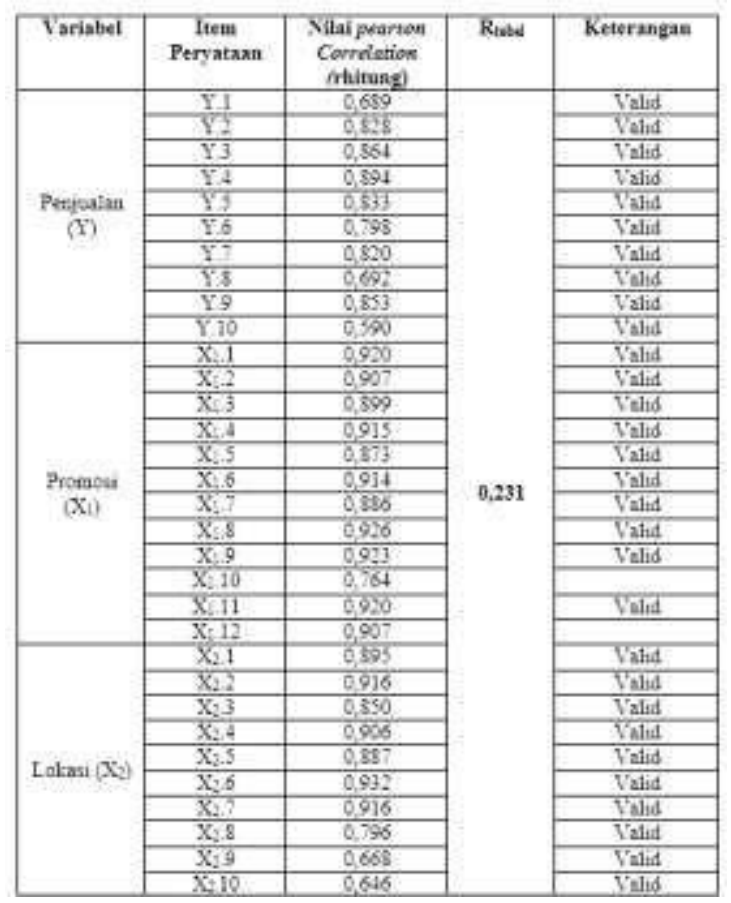

Dapat diketahui nilai $r_{h i t u n g}$ secarakesuluruhan untuk item pernyataan semua variabel dengan tingkat signifikansinya $<0,05$ dan tingkat korelasi $/ r_{\text {hitung }}>r_{\text {tabel }}$ yaitusebesar 0,231, hal tersebut berarti bahwa secara keseluruhan item pernyataanvariabel adalah valid.

Persyaratan data tersebut normal apabilaprobabilitas diatas 0,05.

\begin{tabular}{|c|c|c|}
\hline & & $\begin{array}{l}\text { Unstandardized } \\
\text { Residual }\end{array}$ \\
\hline \multicolumn{2}{|l|}{$\mathrm{N}$} & 72 \\
\hline \multirow{2}{*}{ Normal Parametersat. } & Mean & OE-T \\
\hline & Std. Deviation & 7.08065387 \\
\hline \multirow{3}{*}{ Most Extreme Differences } & Absolute & 105 \\
\hline & Positive & 105 \\
\hline & Negative & -102 \\
\hline \multicolumn{2}{|l|}{ Kolmogorov-Sunirnov Z } & 892 \\
\hline \multicolumn{2}{|l|}{ Asymp. Sig. (2-tanled) } & 404 \\
\hline
\end{tabular}

Berdasarkan Tabel 3 hasil uji normalitas dengan alat bantu komputer yang menggunakan Program SPSS 24, dapat diketahui bahwa besarnya nilai Asymp sig (2-tailed) sebesar 0,404 lebih besar dari0,05. Uji normalitas grafik normal plot dapat dilihat pada gambar 4.1 berikut ini : 
Prosiding The 1st National Conference on Applied Business, Education, \& Technology (NCABET)"

Unversitas Bina Bangsa 2021

DOI Article : 10.46306/ncabet.v1i1.48

Uji Reliabilitas

Tabel 4.Hasil Uii Reliabilitas

\begin{tabular}{|c|c|c|c|c|c|}
\hline \multirow[b]{2}{*}{ No } & \multirow[b]{2}{*}{ Variabel } & \multirow{2}{*}{$\begin{array}{c}\text { Jumbah } \\
\text { Pernysataan }\end{array}$} & \multicolumn{2}{|c|}{ Nilei tiphe } & \multirow[b]{2}{*}{ States } \\
\hline & & & $\begin{array}{l}\text { Crowboch'y } \\
\text { Aipha }\end{array}$ & Standar & \\
\hline 1 & Penjualan (Y) & 10 & 0929 & 0,6 & Reliahel \\
\hline 2 & Promosi $\left(X_{1}\right)$ & 12 & 0,878 & 0,6 & Relisbel \\
\hline 3 & Lokssi $\left(X_{2}\right)$ & 10 & 0.985 & 0,6 & Relisbel \\
\hline
\end{tabular}

Dapat diketahui bahwa Hasil uji reliabilitas menunjukan setiap variabel memiliki Cronbach's Alpha $>0,60$,sehingga dapat disimpulkan bahwa semua item pertanyaan pada semua variabel dikatakan reliable sehingga dapatdilanjutkan untuk penelitian selanjutnya.

\section{Uji Normalitas}

Pengujian distribusi normal dapatdilakukan dengan uji kolmogorov-Smirnov.

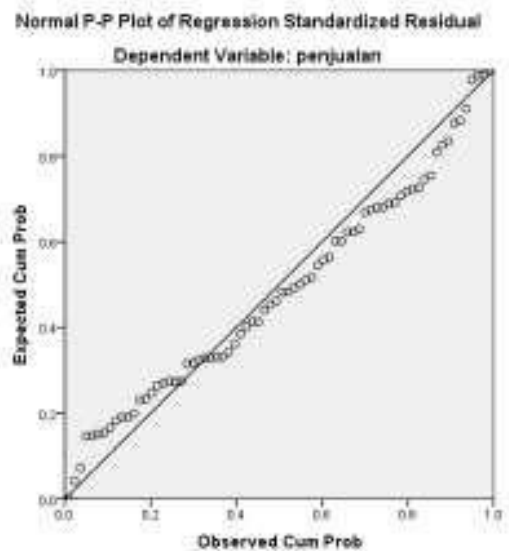

Gambar 2 Hasil Uji Normalitas GrafikNormal Plot

Berdasarkan Gambar 2 dapat disimpulkan bahwa data dalam penelitian berdistribusi normal dikarenakan titik-titik berada disekitar wilayah garis diagonal danmengikuti arah garis diagonal.

\section{Uji Multikolonieritas}

Cara mengetahui ada tidaknya penyimpangan uji multikolinieritas adalah dengan melihat nilai Tolerance dan VIF masing-masing variabel independen, jika nilai Tolerance $>0.10$ dan nilai VIF $<10$, maka data bebas dari gejala multikolinieritas. 
Tabel 5 Hasil Uji Multikolinieritas

Coefficients:

\begin{tabular}{|c|c|c|c|}
\hline \multirow{2}{*}{\multicolumn{2}{|c|}{ Model }} & Collinearity & Collinearity \\
\hline & & Tolerance & VIF \\
\hline \multirow{3}{*}{1} & (Constant) & & \\
\hline & Promosi & 0.039 & 5.737 \\
\hline & Lokasi & 0,039 & 5,373 \\
\hline
\end{tabular}

Dari tabel di atas terlihat bahwa semua variabel mempunyai nilai toleransi di atas 0,1 dan nilai VIF di bawah 10, sehingga dapat disimpulkan bahwa model regresi pada penelitian ini tidak terjadi multikolinieritas.

\section{Uji Heteroskedastisitas}

Hasil pengujian heteroskedastisitas secara rinci dapat dilihat pada gambar 3 berikut:

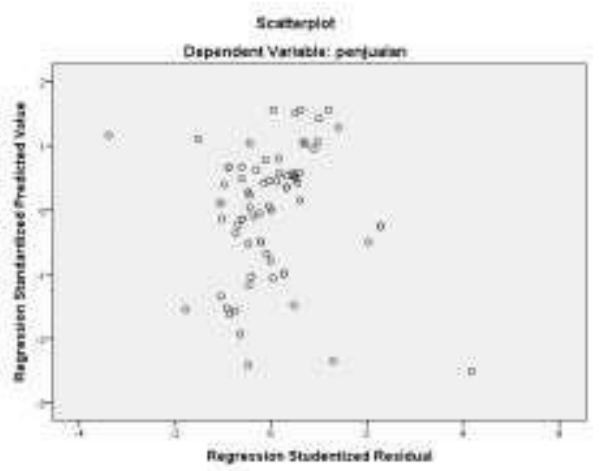

Gambar 3 Hasil Uji Heteroskedastisitas

Hasil uji heteroskedasitas dariGambar 3 menunjukan bahwa grafik scatterplot antara SRESID dan ZPRED menunjukkan pola penyebaran, dimanatitik-titik menyebar secara acak serta tersebar baik diatas maupun dibawah angka0 pada sumbu Y.Regresi Linear Berganda Hasil pengujian regresi linear berganda sebagaiberikut:

Tabel 6 Hasil Analisis Regresi Berganda

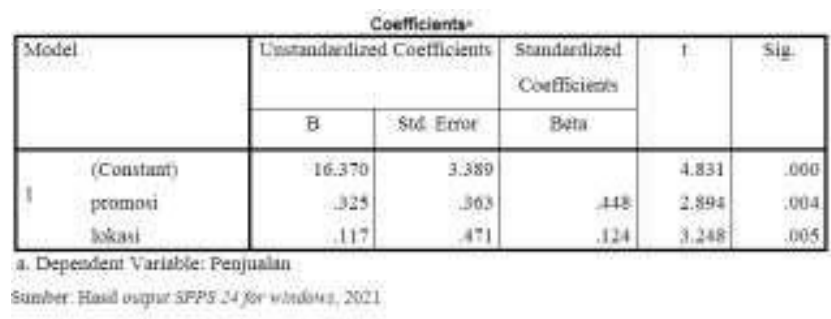

$$
\mathrm{Y}=16.370+0,325 \mathrm{X}_{1}+0,117 \mathrm{X}_{2}
$$

Dengan penjelasan yang terperinci dari persamaan model regresi tersebut dapat diuraikan interpretasinya sebagaiberikut: 
Prosiding The 1st National Conference on Applied Business, Education, \& Technology (NCABET)"

Unversitas Bina Bangsa 2021

DOI Article : $10.46306 /$ ncabet.v1i1.48

a. Konstanta adalah sebesar 16,370 , makajika tidak ada variabel promosi dan lokasi yang mempengaruhi penjualan pada Perumahan Puri Delta Angsana diKecamatan Kasemen Kota Serang, maka penjualan akan sebesar 16,370.

b. Nilai koefisien $(\beta 1)$ promosi sebesar0,325 yang berarti setiap peningkatan promosi yang dilakukan oleh Perumahan Puri Delta Angsana diKecamatan Kasemen Kota Serang 1 (satu) satuan akan meningkatkan penjualan perumahan sebesar 0,325 dengan catatan variabel lain dianggap tetap. Variabel promosi merupakanvariabel yang mempengaruhi penjualandengan koefisien positif sebesar 0,325. Artinya bila variabel promosi semakin kuat, maka penjualan akan semakin tinggi.

c. ilai koefisien ( $\beta 2$ ) lokasi sebesar0,117 yang berarti setiap peningkatan lokasi pada Perumahan Puri DeltaAngsana di Kecamatan Kasemen Kota Serang (satu) satuan akan meningkatkan lokasi perumuhansebesar 0,117 dengan catatan variabel lain dianggap tetap. Variabel lokasi merupakan variabel yang mempengaruhi penjualan dengan koefisien positif sebesar 0,117. Artinya bila atribut lokasi semakin baik, makapenjualan akan semakin tinggi

\section{Analisis Korelasi}

Untuk mengetahui tingkat pengaruh dari wordh of mouth dan celebrity endorser terhadap keputusan pembelian dapat dilihat dari tabel output SPSS sebagai berikut:

Tabel 7 Hasil Output SPSS Koefisien KorelasiBerganda

\begin{tabular}{l|c|c|c|c|}
\hline Model & R & R Square & $\begin{array}{c}\text { Adjusted R } \\
\text { Square }\end{array}$ & $\begin{array}{c}\text { Std. Error of } \\
\text { the Estimate }\end{array}$ \\
\hline 1 & $.571^{\mathrm{a}}$ & .326 & .306 & 7.183 \\
\hline
\end{tabular}
a. Predictors: (Constant), lokasi, promosi
b. Dependent Variable: penjualan
Sumber: Hasil output SPPS 24 for windows, 2021

Berdasarkan tabel diatas, dapat dilihat bahwa sifat korelasi (R) yang ditunjukkan adalah 0,571. Hal ini menunjukkan bahwa hubungan antaravariabel bebas yaitu promosi dan lokasi dengan variabel terikat yaitu penjualan yaitu sedang.

\section{Analisis Koefisien Determinasi}

Kontribusi variabel bebas word of mouth dan celebrity endorser dalam menjelaskan variabel terikat keputusan pembelian dalam persen dapat dilihat nilai koefisiendeterminasi pada tabel dibawah ini: 
Tabel 8 Koefisien Determinasi

\begin{tabular}{|l|r|r|r|r|}
\hline Model & R & R Square & $\begin{array}{c}\text { Adjusted R } \\
\text { Square }\end{array}$ & $\begin{array}{c}\text { Std. Error of } \\
\text { the Estimate }\end{array}$ \\
\hline 1 & $.571^{\mathrm{s}}$ & .326 & .306 & 7.183 \\
\hline
\end{tabular}
a. Predictors: (Constant), lokasi, promosi
b. Dependent Variable: penjualan
Sumber: Hasil output SPPS 24 for windows, 2021

Hasil perhitungan program SPSS diketahui bahwa nilai koefisien determinasi $(R$ Square) yang diperoleh sebesar 0,326. Hal ini berarti 32,6\% variasi penjualan dapat dijelaskan oleh variabel Promosi danLokasi. Sedangkan sisanya 67,4\% dipengaruhi oleh variabel lain yang tidak dimasukkan dalam penelitian. Variabel lainyang tidak dimasukan dalam penelitian ini seperti kualitas pelayanan, harga, kualitas produk dan lain-lain.

\section{Pengujian Hipotesis secara Simultan}

Uji statistik F pada dasarnya menunjukkan apakah semua variabel independen/bebas yang dimasukkan dalam model mempunyai pengaruh secara bersama-sama terhadap variabel dependen/terikat

Tabel 9 Hasil Uji Statististik F

\begin{tabular}{|c|c|c|c|c|c|c|}
\hline \multicolumn{7}{|c|}{ ANOWA } \\
\hline \multicolumn{2}{|c|}{ Model: } & Sum of & df & Mean Sçatte & $F$ & Sit. \\
\hline \multirow{3}{*}{1} & Regrenon & 1719354 & 2 & $8396: 7$ & 16.664 & 0000 \\
\hline & Residual & 3559.632 & 69. & 51589 & & \\
\hline & Toeal & 3278.956 & $7 \mathrm{t}$ & & & \\
\hline
\end{tabular}

Hasil signifikan uji $\mathrm{F}$ yang disajikan pada tabel diatas diketahui bahwa hasil uji $\mathrm{F}$ memiliki nilai signifikan $0,000^{\mathrm{b}}<$ dari nilai taraf signifikansi 0,05 dan nilai $\mathrm{F}$ hitung 16,664 > 3,13 nilai $\mathrm{F}_{\text {tabel. }}$ maka dapat disimpulkan bahwa $\mathrm{H}_{3}$ diterima, yangartinya bahwa Promosi $\left(\mathrm{X}_{1}\right)$, dan Lokasi $\left(\mathrm{X}_{2}\right)$ secara bersama-sama (simultan) mempunyai pengaruh yang signifikan terhadap Penjualan $(\mathrm{Y})$, sehingga hipotesispertama $\left(\mathrm{H}_{3}\right)$ dalam penelitian ini yang menyatakan bahwa "promosi dan lokasi secara bersama diduga berpengaruh terhadap penjualan pada Perumahan Puri Delta Angsana di Kecamatan Kasemen Kota Serang” diterima atau terbukti.

Pengaruh Promosi Terhadap Penjualan Perumahan Puri Delta Angsana di Kecamatan Kasemen Kota Serang

Hasil uji hipotesis secara parsial menunjukan promosi mempunyai nilai t- hitung sebesar 2,894. Jika dibandingkan dengan nilai $t_{\text {tabel }}$ sebesar 1,666 maka t- hitung yang diperoleh lebih besar dari nilai t-tabel. Nilai signifikan sebesar 0,004 yang lebih kecil dari 0,05 dan nilai Standardized 
Prosiding The 1st National Conference on Applied Business, Education, \& Technology (NCABET)"

Unversitas Bina Bangsa 2021

DOI Article : 10.46306/ncabet.v1i1.48

Coefficient menunjukan arah positif yaitu 0,325. Hal ini berarti bahwa semakin menarik promosi yang dilakukan oleh perusahaan akan semakin meningkatkan volume penjualan terhadap produk rumahyang ditawarkan. Hasil penelitian inimengacu pada penelitian yang dilakukan oleh Abdul Haris Romdhoni, Dian Indah Cahyani (2019) harga, lokasi, dan promosi secara bersama-sama berpengaruhsignifikan terhadap penjualan (Y).

\section{Pengaruh Lokasi Terhadap Penjualan Perumahan Puri Delta Angsana diKecamatan Kasemen Kota Serang}

Hasil uji hipotesis secara parsial menunjukan lokasi mempunyai nilai nilai thitung sebesar 3,248. Jika dibandingkandengan nilai $t_{\text {tabel }}$ sebesar 1,666 maka t-hitungyang diperoleh lebih besar dari nilai t-tabel. Nilai signifikan sebesar 0,005 yang lebih kecil dari 0,05dan nilai Standardized Coefficient menunjukan arah positif yaitu 0,117 . Hal ini berarti bahwa semakinstrategis lokasi yang ditawarkan oleh perusahaan, akan semakin meningkatkanvolume penjualan terhadap produk rumah yang ditawarkan. Hasil penelitian ini mengacu pada penelitian yang dilakukan oleh Abdul Haris Romdhoni, Dian Indah Cahyani (2019) dan Elina Monica (2018) Hasil penelitian menunjukkan bahwa terdapat pengaruh yang signifikan antara variabel lokasi terhadap penjualan dalam perumahan.

\section{Pengaruh Promosi dan Lokasi TerhadapPenjualan Perumahan Puri DeltaAngsana di Kecamatan Kasemen Kota Serang}

Berdasarkan hipotesis secara simultan menunjukkan bahwa Promosi $\left(\mathrm{X}_{1}\right)$, dan Lokasi $\left(\mathrm{X}_{2}\right)$ secara bersama-sama(simultan) mempunyai pengaruh yang signifikan terhadap Penjualan (Y), dengan nilai signifikan $0,000^{\mathrm{b}}<$ dari nilai tarafsignifikansi 0,05 dan nilai $\mathrm{F}_{\text {hitung }} 16,664>3,13$ nilai $\mathrm{F}_{\text {tabel. }}$. Hasil penelitian ini mengacu pada penelitian yang dilakukan oleh Abdul Haris Romdhoni, Dian Indah Cahyani (2019) dan Elina Monica (2018). Hasil penelitian menunjukkan bahwaterdapat pengaruh yang signifikan antara variabel promosi dan lokasi terhadap penjualan dalam perumahan.

\section{KESIMPULAN DAN SARAN}

Berikut adalah kesimpulan yang bisa diambil dalam penelitian ini :

1. Berdasarkan hasil penelitian promosi secara parsial berpengaruh signifikan terhadap penjualan pada Perumahan Puri Delta Angsana di Kecamatan Kasemen Kota Serang

2. Berdasarkan hasil penelitian lokasi secara parsial berpengaruh signifikan terhadap penjualan pada Perumahan Puri Delta Angsana di Kecamatan Kasemen Kota Serang

3. Berdasarkan hasil penelitian Promosi $\left(\mathrm{X}_{1}\right)$, dan Lokasi $\left(\mathrm{X}_{2}\right)$ secara bersama- sama 
Prosiding The 1st National Conference on Applied Business, Education, \& Technology (NCABET)"

Unversitas Bina Bangsa 2021

DOI Article : 10.46306/ncabet.v1i1.48

(simultan) berpengaruhsignifikan terhadap Penjualan (Y)pada Perumahan Puri Delta

Angsana di Kecamatan Kasemen Kota Serang

\section{UCAPAN TERIMAKASIH /ACKNOWLEDGEMENTS}

Penulis mengucapkan banyak terima kasih sebanyak-banyaknya pada staf pemasaran perumahan puri Delta Angsana Di Kecamatan Kasemen Kota Serang yang telah membantu saya dalam menyelesaikan penelitian ini baik dari pemberian data dan lain sebagainya. Begitu bagi pihak lain yang tidak bisa saya sebutkan, saya ucapkan terima kasih. Terutama kepada Rektor Kampus UNIBA Serang dan Ketua Program Studi Manajemen yang telah memotivasi saya untuk mnyelesaikan penelitian ini.

\section{DAFTAR PUSTAKA}

Abdul Haris Romdhoni1), Dian IndahCahyani (2019). Pengaruh Harga, Lokasi, Dan Promosi TerhadapVolume Penjualan Dalam Pembelian Perumahan di PT. Gemilang JayaAbadi. Jurnal Education andEconomics, 2(4), 403-408.

Abdullah, T., \& Tantri, F. (2016).Manajemen Pemasaran. Depok: PT Raja Grafindo Persada. Ardista, R., Wulandari, A. (2020). AnalisisPengaruh Harga, Lokasi Dan Gaya Hidup Terhadap Keputusan Pembelian. Jurnal Manajemen dan Akuntansi, 15(2), 1-13. DOI : https://doi.org/10.32534/jv.v15i2.1156

Baradi, E. G. (2014. Analisis pengaruh tingkat pendapatan, jumlahtanggungan keluarga, tingkat pendidikan, usia dan lokasi perumahanterhadap permintaan kredit pemilikan rumah bank BTN (studi kasus kota Malang). Jurnal Ekonomi dan Bisnis, 12(7), 1-9.

Ghozali, I. (2015) Aplikasi Analisis Multivariate dengan Program IBM SPSS 2 Semarang : Badan Penerbit Universitas Diponegoro.

Haryani, D. S (2019). The Influence OfAdvertising And Sales Promotion Towards Housing PurchasingDecisions On Griya Puspandari Asri Tanjungpinang. DIMENSI, 8(1), 54-70.

Hutabarat, E. (2017). Pengaruh PromosiDalam Meningkatkan Volume Penjualan Pada Toko Buku Gramedia Sun Plaza Medan, Jurnal Ilmiah Methonomi, 3(2), 83-91.

Ida HidayahTeguh Ariefiantoro2 Dwi Widi Pratito Sri Nugroho (2021). Analisis Strategi Bauran Pemasaran Dalam Meningkatkan Volume Penjualan(Studi Kasus Pada Pudanis di Kaliwungu). SOLUSI: Jurnal IlmiahBidang Ilmu Ekonomi, 19(1), 76-82.

Kesuma, M., Fitria, D., Ulil, A., \& Al Umar, A. (2021). Pengaruh Harga, Kualitas Produk Dan Promosi Terhadap Keputusan Pembelian Produk Pattaya Corner Kota Salatiga, Jurnal 
Prosiding The 1st National Conference on Applied Business, Education, \& Technology (NCABET)"

Unversitas Bina Bangsa 2021

DOI Article : $10.46306 /$ ncabet.v1i1.48

Ilmiah Manajemen Ubhara, 3(1), 13-21.

Kotler, P., \& Keller, K. L. (2016). Marketing Managemen, 15th Edition, Pearson Education,Inc.

Kuspriyono, T. (2018). Pengaruh Iklan Terhadap Keputusan Pembelian Apartemen Meikarta. JurnalCakrawala, 18(1), 59-66.

Kustiyah, E., \& Irawan. (2017). HubunganBauran Pemasaran Dengan Volume Penjualan Di Pasar Malam NgarsopuraSurakarta, Jurnal Paradigma, 12(1), 1-11.

Marwanto, A. (2015). Marketing Sukses.Yogjakarta: KOBIS.

Mursid. (2013). Manajemen Pemasaran (Jakarta: PT Bumi Aksara) 